\title{
Dieta y amplitud del nicho trófico del cormorán neotropical [Nannopterum brasilianus (Gmelin, 1789)] en el Santuario de Flora y Fauna Ciénaga Grande de Santa Marta, Caribe de Colombia
}

\author{
Diet and trophic niche breadth of the neotropical cormorant \\ [Nannopterum brasilianus (Gmelin, 1789)] in the Flora and Fauna \\ Sanctuary Ciénaga Grande de Santa Marta, Caribbean Colombia
}

\author{
Aliano Tette-Pomarico ${ }^{*}$, Arístides López-Peña ${ }^{2}$, Rebeca Franke-Ante ${ }^{3}$ y Luis Orlando Duarte ${ }^{4}$ \\ $\begin{array}{llll}\text { (iD) } 0000-0003-2804-864 X & \text { (iD } 0000-0002-9401-9348 & \text { (iD } 0000-0002-0956-0915 & \text { (iD } 0000-0001-5494-5390\end{array}$
}

1. Universidad del Magdalena, Santa Marta,Colombia.alianottpomarico@hotmail.com*

2. Santuario de Flora y Fauna Ciénaga Grande de Santa Marta, Parques Nacionales Naturales de Colombia, Ciénaga, Colombia. aristideslpz@gmail.com

3. Dirección Territorial Caribe, Parques Nacionales Naturales de Colombia, Santa Marta, Colombia. rebeca.franke@parquesnacionales.gov.co

4.Universidad del Magdalena, Santa Marta, Colombia. gieep@unimagdalena.edu.co

* Autor de correspondencia.

\section{RESUMEN}

$\mathrm{E}$ 1 cormorán neotropical (Nannopterum brasilianus) es un ave piscívora con reproducción colonial. Se distribuye desde el sur de Norteamérica hasta Argentina. La colonia más grande en Colombia se encuentra en la localidad de Punta Blanca, localizada en el Santuario de Flora y Fauna Ciénaga Grande de Santa Marta (SFF CGSM), en el complejo lagunar del mismo nombre (CL CGSM). En el presente estudio se analizó la dieta y la amplitud de nicho de $N$. brasilianus a partir de egagrópilas recolectadas en el borde occidental de la colonia de anidación de Punta Blanca durante la época reproductiva de 2017. La identificación de presas se basó principalmente en la morfología de los otolitos de peces encontrados en las egagrópilas $(\mathrm{n}=64)$. Se identificaron ocho especies de peces en la dieta de $N$. brasilianus, de las cuales tres fueron nuevos registros para la dieta de la población del complejo lagunar (Mugil liza, M. curema y M. cephalus). Se destacó la representatividad de Cathorops mapale como principal presa consumida durante el estudio (89,5\% en número y $91,8 \%$ en frecuencia de ocurrencia). Se observó una amplitud de nicho trófico estrecha (Levin's de 0,002 ) y una dieta con baja equitatividad $(\mathrm{q} 2=2,1)$, lo que corresponde a una respuesta adaptativa modelada por la disponibilidad de presas.

PALABRAS CLAVES: aves acuáticas, ciénagas, ecosistemas costeros, Phalacrocoracidae

\section{ABSTRACT}

$\mathrm{T}$ The neotropical cormorant (Nannopterum brasilianus) is a piscivorous bird with colonial nesting. It is distributed from southern North America to Argentina. The largest colony of N. brasilianus in Colombia is located in the locality of Punta Blanca, in the Flora and Fauna Sanctuary Ciénaga Grande de Santa Marta (FFS CGSM), in the lagoon complex with same name (LC CGSM). The diet and niche width of $N$. brasilianus were analyzed from pellets collected on the western edge of the Punta Blanca nesting colony during the breeding season of 2017. Prey identification was based on mainly on the morphology of the fish otoliths found in these pellets $(\mathrm{n}=64)$. There were eight fish species identified in the diet of $N$. brasilianus of which three are new records for the diet of the population of the lagoon complex (Mugil liza, M. curema y M. cephalus). It is highlighted the representativeness of Cathorops mapale is reported, as the main prey consumed during the study ( $89.5 \%$ in number and $91.8 \%$ in frequency of occurrence). A narrow trophic niche breadth was observed (Levin's 0.002 ) and a diet with low equitability ( $\mathrm{q} 2=2.1$ ), which corresponds to an adaptive response modeled by the availability of prey.

KEY WORDS: acuatic birds, swamps, coastal ecosystems, Phalacrocoracidae

DOI: https://doi.org/10.25268/bimc.invemar.2020.49.SuplEsp.1072

Publicado por INVEMAR

Published by INVEMAR

Este es un manuscrito de acceso abierto bajo la licencia CC

Reconocimiento-No Comercial-Compartir Igual 


\section{INTRODUCCIÓN}

El sitio Ramsar Sistema Delta Estuarino del río Magdalena o complejo lagunar Ciénaga Grande de Santa Marta (CL CGSM) alberga altas concentraciones de aves acuáticas tanto residentes como migratorias, por lo que ha sido categorizado como un área de importancia para la conservación de las aves (Ruiz-Guerra et al., 2008; BirdLife International, 2018). En su interior existen dos áreas protegidas de carácter nacional administradas por Parques Nacionales Naturales de Colombia: el Vía Parque Isla de Salamanca (VIPIS) y el Santuario de Flora y Fauna Ciénaga Grande de Santa Marta (SFF CGSM).

El CL CGSM ha sido afectado desde finales de 1960 por acciones humanas tanto en su interior como en sus afluentes, generando un desequilibrio hidrológico del sistema, la pérdida de bosque de manglar y la reducción de las poblaciones de peces, moluscos y crustáceos, los cuales juegan un papel fundamental en el funcionamiento del ecosistema y sustentan la pesquería artesanal, de la que dependen diferentes poblaciones locales (Botero y Salzwedel, 1999; Sánchez-Ramírez y Rueda, 1999; Lorenz y Serafy, 2006). Si bien se han realizado obras de rehabilitación hídrica, siguen presentándose afectaciones dentro del sistema (Invemar, 2019). Esta situación es percibida por los pobladores locales y por diferentes actores vinculados al sistema como la causante de una disminución en aproximadamente la mitad de los servicios ecosistémicos del humedal, lo cual amerita mayores esfuerzos de conservación (Vilardy et al., 2012; Invemar, 2019).

Los estudios de ecología trófica son cruciales para la conservación de ecosistemas amenazados, debido a que proporcionan información importante sobre el rol funcional de las especies y sus hábitats (Bó et al., 2007). Entre los aspectos más importantes de la ecología trófica se encuentra la composición dietaría, la partición de recursos tróficos y la amplitud de nicho alimentario, ya que permiten incrementar el conocimiento sobre las interacciones tróficas de un depredador con sus presas y sus implicaciones en la conservación y preservación de las especies y del ecosistema (López-Calleja, 1995; Bó et al., 2007). Estos aspectos pueden variar con la abundancia de las presas, hábitats y/o sitios geográficos y pueden ser modelados, entre otros, con la teoría de forrajeo óptimo, que predice un aumento en la amplitud de nicho y en la diversidad de presas frente a la reducción en la disponibilidad de sus presas más optimas y una mayor especificidad al aumentar la disponibilidad

\section{INTRODUCTION}

The Magdalena River Estuary Delta System Ramsar Site of Ciénaga Grande de Santa Marta Lagoon Complex (CGSM LC) is home to high concentrations of both resident and migratory waterfowl, which is why it has been categorized as an area of importance for bird conservation. (Ruiz-Guerra et al., 2008; BirdLife International, 2018). There are two national protected areas administered by National Natural Parks of Colombia: the Vía Parque Isla de Salamanca (VIPIS) and the Ciénaga Grande de Santa Marta Flora and Fauna Sanctuary (CGSM FFS).

The CGSM LC has been affected since the late 1960 s by human actions both in its interior and in its tributaries, generating a hydrological imbalance in the system, the loss of mangrove forest, and the reduction of fish, mollusk, and crustacean populations; which play a fundamental role in the functioning of the ecosystem and sustaining artisanal fishery, on which different local populations depend (Botero and Salzwedel, 1999; SánchezRamírez and Rueda, 1999; Lorenz and Serafy, 2006). Although water rehabilitation works have been carried out, conditions continue to appear within the system (Invemar, 2019) This situation is perceived by local inhabitants and by different actors linked to the system as the cause of a decrease in approximately half of the ecosystem services of the wetland, which warrants greater conservation efforts (Vilardy et al., 2012; Invemar, 2019).

Trophic ecology studies are crucial for the conservation of threatened ecosystems because they provide important information on the functional role of species and their habitats (Bó et al., 2007). Among the most important aspects of trophic ecology is the dietary composition, the partition of trophic resources, and the breadth of the food niche, since they allow increasing knowledge about the trophic interactions of a predator with its prey and its implications for conservation and preservation of species and the ecosystem (López-Calleja, 1995; Bó et al., 2007). These aspects may vary with the abundance of prey, habitats, and/or geographic sites and are modeled with the optimal foraging theory, which predicts an increase in niche width and prey diversity versus a reduction in the availability of their most optimal prey, and greater specificity by increasing their availability (Valdovinos et al., 2010; Román-Palacios and RománValencia, 2015). In cormorants, trophic ecology studies 
de estas (Valdovinos et al., 2010; Román-Palacios y Román-Valencia, 2015). En cormoranes los estudios de ecología trófica aportan bases para comprender su rol en los ecosistemas acuáticos, su influencia en la comunidad íctica y su interacción con poblaciones de pescadores (Dias et al., 2012).

La principal colonia reproductiva del cormorán neotropical (Nannopterum brasilianus) de Colombia está ubicada en el CL CGSM, al noroccidente del SFF CGSM (Figura 1). Se estima que esta colonia puede superar los 30000 individuos (Ruiz-Guerra et al., 2008; Ruiz-Guerra et al., 2012). Estudios tróficos previos han determinado que $N$. brasilianus es un ave piscívora y generalista, que se alimenta mediante buceo y zambullida en medios marinos, dulceacuícolas y estuarinos (Gil de Weir et al., 2011; CondeTinco y Iannacone, 2013). Esta especie elimina las partes de las presas que no puede digerir, regurgitando egagrópilas generalmente una vez al día (Orta, 1992; Zijlstra y VanEerden, 1995).

El cormorán presenta una alta plasticidad que le permite adaptarse a la disponibilidad de presas, observándose casos como el del lago Dos Patos (Brasil) donde, siendo una especie generalista, cambia su estrategia a especialista durante una parte del año, condición que Barquete et al. (2008) llamaron "especialización temporal". A la fecha se han reconocido como parte de la dieta del cormorán neotropical los peces óseos bentónicos o mesopelágicos de las familias Ariidae, Engraulidae, Sciaenidae, Mugilidae y Gerreidae (Barquete et al., 2008; Muñoz et al., 2008; Gil de Weir et al., 2011). El único antecedente de la dieta de $N$. brasilianus en el CL CGSM fue realizado por Hennig (1997), cuyo estudio coincidió con las acciones de rehabilitación en el complejo lagunar de 1995-1999 y los eventos de muerte masiva de peces de 1994-2000.

El conocimiento sobre la ecología trófica de $N$. brasilianus dentro el CL CGSM es importante considerando su tamaño poblacional y su rol como depredador de peces, lo que le confiere influencia en la estructura y función de los humedales (Smith y Smith, 2001; Begon et al., 2005). El presente estudio pretender aportar información de la ecología trófica de $N$. brasilianus durante su periodo de nidación en el CL CGSM en 2017. Para ello se revisó la composición taxonómica de la dieta, la amplitud de nicho alimentario, la riqueza de presas, la diversidad trófica y la equitatividad de presas. Los resultados obtenidos se analizaron en el contexto de estudios previos realizados en Latinoamérica. provide the basis for understanding their role in aquatic ecosystems, their influence on the fish community, and their interaction with fishing populations (Dias et al., 2012).

The main reproductive colony of the Neotropical cormorant (Nannopterum brasilianus) from Colombia is located in the CGSM LC, northwest of the CGSM FFS (Figure 1). It is estimated that this colony can exceed 30000 individuals (Ruiz-Guerra et al., 2008; Ruiz-Guerra et al., 2012). Previous trophic studies have determined that $N$. brasilianus is a generalist and piscivorous bird, which feeds by diving in marine, freshwater, and estuarine environments (Gil de Weir et al., 2011; Conde-Tinco and Iannacone, 2013). This species eliminates the parts of the prey that it cannot digest, regurgitating pellets generally once a day, just before dawn or going out to forage (Orta, 1992; Zijlstra and Van-Eerden, 1995).

The cormorant has high plasticity that allows it to adapt to the availability of prey, observing cases such as Dos Patos Lake (Brazil) where it is a generalist who presents a breadth of specialist niche during part of the year, a condition that Barquete et al. (2018) called "temporal specialization". To date, benthic or mesopelagic bony fishes of the Ariidae, Engraulidae, Sciaenidae, Mugilidae, and Gerreidae families have been recognized as part of the diet of the Neotropical cormorant (Barquete et al., 2008; Muñoz et al., 2008; Gil de Weir et al., 2011). The only antecedent of the N. brasilianus diet in the CGSM LC was made by Hennig (1997), whose study coincided with the rehabilitation actions in the lagoon complex in 1995-1999 and the massive fish death events of 1994-2000.

Knowledge about the trophic ecology of $N$. brasilianus within the CGSM LC is important considering its population size and its role as a fish predator which could give it an influence on the structure and function of wetlands (Smith and Smith, 2001; Begon et al., 2005). The present study aims to provide information on the trophic ecology of $N$. brasilianus during its nesting period in the CGSM LC in 2017. For this, the taxonomic composition of the diet, the breadth of the food niche, the richness of prey, the trophic diversity, and prey fairness; by minimally invasive pellet analysis. The results obtained were analyzed in the context of previous studies carried out in Latin America. 


\section{ÁREA DE ESTUDIO}

La colonia reproductiva de $N$. brasilianus se encuentra ubicada en el sector nororiental del SFF CGSM, entre la desembocadura del río Aracataca y la desembocadura de caño Pájaro (Figura 1). El clima del CL CGSM es tropical árido, ya que la acción de los vientos alisios al norte de los $10^{\circ} \mathrm{N}$ es suficiente durante todo el año para inhibir en gran medida las precipitaciones, presentándose temperaturas promedio anuales entre $27^{\circ}$ y $30^{\circ} \mathrm{C}$ en la columna de agua y una humedad relativa entre 50-100 \% (Andrade-Amaya, 2000; Blanco et al., 2006). El régimen anual de lluvias varía entre 401 y $1321 \mathrm{~mm}$, con un promedio de $897 \mathrm{~mm} /$ año, el cual se distribuye en un patrón climático unimodal con un periodo de vientos entre diciembre y abril, y un periodo de calmas, en el cual se observan las precipitaciones de mayo a noviembre, teniendo un máximo de pluviosidad entre septiembre y noviembre (Blanco et al., 2006; García et al., 2013).

\section{STUDY AREA}

The reproductive colony of $N$. brasilianus is located in the northeastern sector of the CGSM FFS, between the mouth of the Aracataca River and the mouth of Caño Pájaro (Figure 1). The climate of the CGSM LC is tropical arid since the action of the trade winds north of $10^{\circ} \mathrm{N}$ is sufficient throughout the year to greatly inhibit precipitation, with average annual temperatures between $27^{\circ}$ and $30^{\circ} \mathrm{C}$ in the water column and relative humidity between 50-100 \% (Andrade-Amaya, 2000; Blanco et al., 2006). The annual rainfall regime varies between 401 and $1321 \mathrm{~mm}$, with an average of $897 \mathrm{~mm} /$ year, which is distributed in a unimodal climatic pattern with a period of winds between December and April, and a period of calm, in which rainfall from May to November, with maximum rainfall between September and November (Blanco et al., 2006; García et al., 2013).

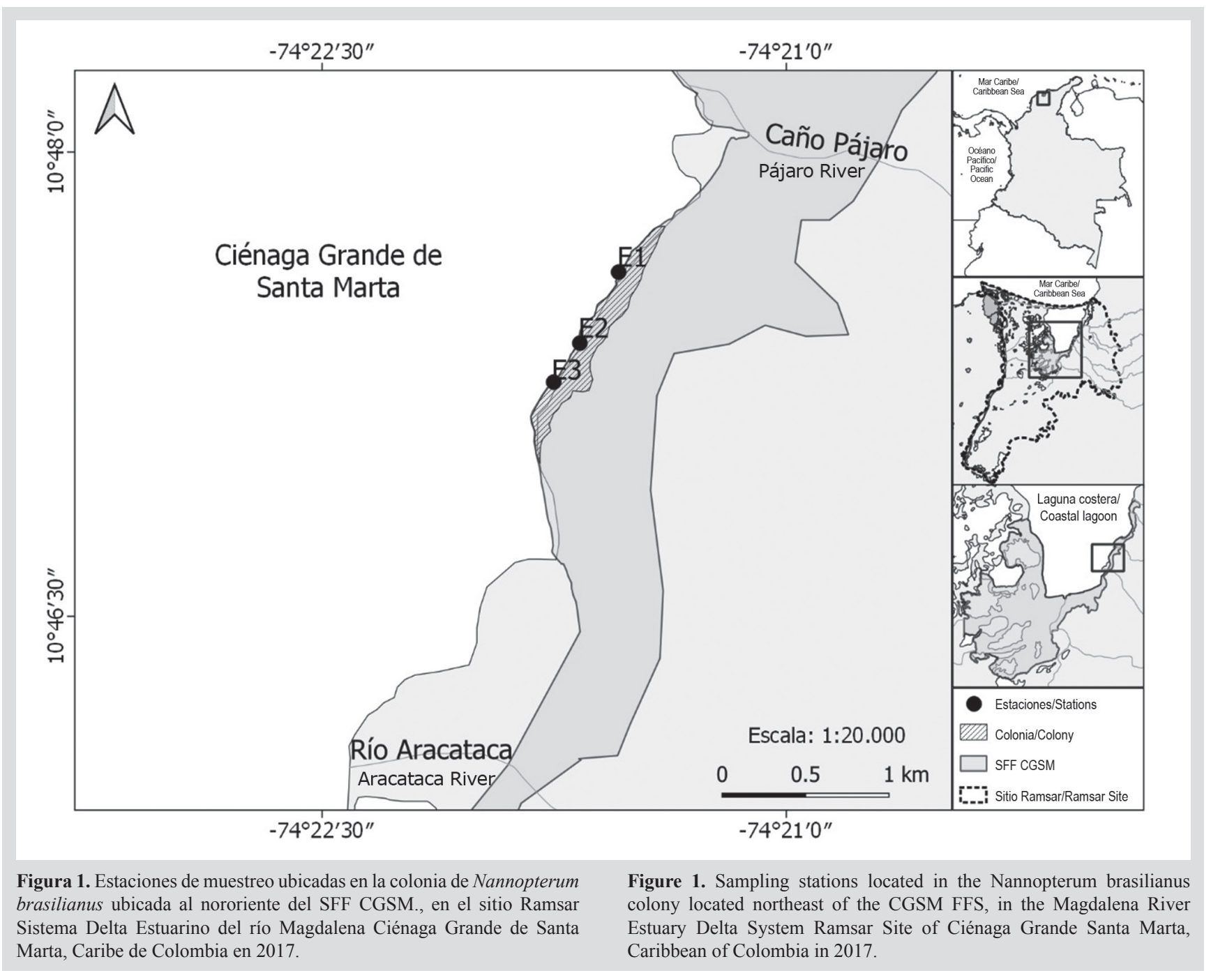




\section{MATERIALES Y MÉTODOS}

Fase de campo

El muestreo se efectuó semanalmente entre mayo (cuatro semanas) y junio (dos semanas) de 2017 coincidiendo con el periodo reproductivo de $N$. brasilianus en ese año. Se visitaron tres estaciones de muestreo entre las 9 y 11 a. m., seleccionadas previamente por su accesibilidad y disposición de material para recolectar, evitando estresar a las aves según lo proponen Olmos et al. (2000) y Petraci et al. (2009). La recolección de egagrópilas se realizó manualmente con ramas, hojas y raíces de mangle, con el esfuerzo de dos recolectores durante 30-35 min por sitio. Las egagrópilas se guardaron en seco dentro de bolsas con sello hermético, rotuladas externamente con sellos adhesivos e internamente con etiquetas de papel pergamino, y se refrigeraron por menos de dos horas hasta ser llevadas a procesar en el laboratorio.

Fase de laboratorio

Las egagrópilas se lavaron con etanol al $70 \%$ y se desintegraron con la ayuda de pinzas y lancetas para separar los restos óseos como mandíbulas, otolitos, vértebras y demás restos del material. Las estructuras óseas encontradas se lavaron y almacenaron en etanol al $70 \%$ (Olmos et al., 2000). Los otolitos de peces óseos se utilizaron para la identificación del componente íctico hasta el nivel taxonómico más bajo posible utilizando diferentes guías de identificación (Abilhoa y Correa, 1992; Volpedo y Echeverría, 2000; Hernández-García et al., 2004; Martínez et al., 2007; Espino-Barr et al., 2013) y las bases de datos de otolitos Anàlisi de FORmes d'Otòlits (AFORO) y COSSBRASIL (Lombarte et al., 2006; Rossi-Wongtschowski et al., 2016). El trabajo de caracterización de otolitos de Rossi-Wongtschowski et al. (2016) fue utilizado para la descripción de los otolitos tipo sagitta. La descripción de los otolitos tipo asteriscus se basó en Assis (2003) y para los otolitos tipo lapillus se basó en Assis (2005). Para las descripciones de los otolitos se utilizó un microscopio estereoscópico Leica M205A y se fotografiaron con una cámara integrada Leica DFC450.

Análisis de datos

Para evaluar la representatividad o completitud de la muestra, estimado como la cobertura de muestreo según Chao et al. (2014), se empleó el estimador ( $\left.\hat{\mathrm{C}}_{\mathrm{ind}}\right)$. Dicho análisis se realizó mediante el paquete estadístico iNEXT, en el entorno de programación RStudio V.1.3.959

\section{MATERIALS AND METHODS}

Field phase

The sampling was carried out weekly between May (four weeks) and June (two weeks) of 2017, coinciding with the reproductive period of $N$. brasilianus in that year. Three sampling stations were visited between 9 and 11 a.m., previously selected for their accessibility and availability of material to collect, avoiding stressing the birds as proposed by Olmos et al. (2000) and Petraci et al. (2009). The pellet collection was performed manually from mangrove branches, leaves and roots, with the effort of two collectors for 30-35 min per site. The pellets were stored dry in hermetically sealed bags, externally labeled with adhesive seals and internally with parchment paper labels, and were refrigerated for less than two hours until they were taken to the laboratory for processing.

Laboratory phase

The pellets were washed with $70 \%$ ethanol, disintegrated with the help of forceps and lancets to separate the bone remains such as jaws, otoliths, vertebrae, and other remains of the material. The bone structures found were washed and stored in $70 \%$ ethanol (Olmos et al., 2000). The bony fish otoliths were used for the identification of the fish component down to the lowest possible taxonomic level using different identification guides (Abilhoa and Correa, 1992; Volpedo and Echeverría, 2000; Hernández-García et al., 2004; Martínez et al., 2007; Espino-Barr et al., 2013) and the Anàlisi de FORmes d'Otòlits (AFORO) and COSSBRASIL (Lombarte et al., 2006; Rossi-Wongtschowski et al., 2016). The otolith characterization work by RossiWongtschowski et al. (2016) was used for the description of the sagitta-type otoliths. The description of asteriscustype otoliths was based on Assis (2003) and for lapillus-type otoliths it was based on Assis (2005). For descriptions of the otoliths, a Leica M205A stereomicroscope was used and they were photographed with an integrated Leica DFC450 camera.

\section{Analysis of data}

To evaluate the representativeness or completeness of the sample, estimated as the sampling coverage according to Chao et al. (2014), the estimator $\left(\hat{\mathrm{C}}_{\text {ind }}\right)$. This analysis was carried out using the iNEXT statistical package, in the RStudio V.1.3.959 programming environment (Hsieh et al., 2016; RStudio, 2020). For this, each pellet was taken as the sampling unit, assuming that each bird generally throws one 
(Hsieh et al., 2016; RStudio, 2020). Para ello se tomó como unidad de muestreo cada egagrópila, asumiendo que cada ave arroja generalmente una egagrópila en la mañana antes del forrajeo (Orta, 1992; Zijlstra y Van-Eerden, 1995). Para determinar la composición alimentaria de la dieta se utilizaron dos medidas relativas de cuantificación de presas, detalladas por Hureau (1970) e Hyslop (1980) para el análisis de contenidos estomacales:

(1) Frecuencia de ocurrencia (\%FO), que expresa el porcentaje de ocurrencia de cada una de las presas y se calculó como:

$$
\% F O=\frac{n}{N} \times 100
$$

Donde:

$n$ es el número de egagrópilas en las que estuvo presente la presa $i$, y

$N$ es el número total de egagrópilas observadas.

(2) Porcentaje en número $(\% \mathrm{~N})$, que explica la proporción numérica de cada presa presente en relación al total de individuos de todas las presas y se calculó como:

$$
\% N=\frac{N_{n}}{N_{p}} \times 100
$$

Donde:

$N_{n}$ es el número de individuos de la presa $i$ encontrados en la egagrópila $j$, y

$N_{p}$ es el número total de individuos de todas las presas encontrados en todas las egagrópilas.

Para calcular la amplitud del nicho trófico se usó el índice de Levins Estandarizado $\left(B_{j}\right)$, a partir de la medición de la uniformidad en los individuos consumidos. Los valores de $B_{j}$ oscilan entre 0 y 1 , siendo los valores superiores a 0,6 propios de especies generalistas, mientras que valores inferiores corresponden a especies especialistas (Krebs, 1989). Su ecuación es:

$$
B_{j}=\frac{1}{n-1} \times\left\{\left[\frac{1}{\sum p_{i j}^{2}}\right]-1\right\}
$$

Donde:

$n$ es el número de ítems presa consumidos por la especie, y $p$ es la probabilidad de hallar el ítem $(i)$ en la muestra $(j)$. pellet in the morning before foraging (Orta, 1992; Zijlstra and Van-Eerden, 1995). To determine the food composition of the diet, two relative measures of prey quantification were used, detailed by Hureau (1970) and Hyslop (1980) for analysis of stomach contents:

(1) Frequency of Occurrence (\%FO): expresses the percentage of occurrence of each of the dams (Hyslop, 1980) and is calculated as:

$$
\% F O=\frac{n}{N} \times 100
$$

Where,

$n$ is the number of pellets in which prey $i$ was present, and $N$ is the total number of pellets observed.

(2) Numerical Frequency $(\% \mathrm{~N})$ : explains the numerical frequency of each prey present in relation to the total number of individuals of all prey and is calculated by:

$$
\% N=\frac{N_{n}}{N_{p}} \times 100
$$

Where,

$N_{\mathrm{n}}$ is the number of individuals from prey $i$ found in the pellet $j$, and

$N_{\mathrm{p}}$ is the total number of individuals from all prey in pellets.

On the other hand, to calculate the breadth of the trophic niche, the Standardized Levins index $\left(B_{j}\right)$ was used, based on the measurement of uniformity in the individuals consumed. The values of $B_{j}$ oscillate between 0 and 1 , with values higher than 0.6 typical of generalist species, while lower values correspond to specialist species (Krebs, 1989). Its equation is:

$$
B_{j}=\frac{1}{n-1} \times\left\{\left[\frac{1}{\sum p_{i j}^{2}}\right]-1\right\}
$$

Where,

$n$ is the number of prey items consumed by the species, and $p$ is the probability of finding the item $(i)$ in the sample $(j)$. 
La riqueza de especies en la dieta, diversidad trófica y equitatividad de las presas se calcularon con los números Hill. Estos son una medida de diversidad que permite una interpretación unificada e intuitiva en unidades de especies efectivas con base en datos de abundancia relativa (Jost, 2006). Para la estimación de los números Hill se utilizó el modelo propuesto por Chao et al. (2014) para datos de frecuencia de incidencia incluido en la función "iNEXT()" del paquete iNEXT (Hsieh et al., 2016). Los números Hill presentan un exponente $q$ que determina su sensibilidad a la frecuencia de incidencia, siendo $q=0$ equivalente a la riqueza de especies, $q=1$ a la diversidad y $q=2$ la equitatividad (Hill, 1973; Chao et al., 2014).

\section{RESULTADOS}

Se colectó un total de 76 egagrópilas, en las cuales se encontraron restos de peces, moluscos y crustáceos, con un promedio de $4,4 \pm 2,8$ peces por egagrópila (Figura 2). La cobertura de la muestra $\left(\hat{\mathrm{C}}_{\text {ind }}=0,94, \mathrm{IC}=0,95\right)$ indicó que los resultados fueron representativos de la dieta de N. brasilianus para el periodo de mayo-junio del 2017. El intervalo de confianza mostró que la probabilidad de encontrar una nueva especie si se agregara una nueva egagrópila a la muestra es de $0,06\left(1-\hat{\mathrm{C}}_{\text {ind }}\right)$ (Figura 3 ).

En las egagrópilas se encontraron restos de material no digerido de tres grupos: i) crustáceos, representado
Diet species richness, trophic diversity, and prey fairness were calculated with Hill numbers. These are a measure of diversity that allows a unified and intuitive interpretation in effective species units based on relative abundance data (Jost, 2006). To estimate the Hill numbers, the model proposed by Chao et al. (2014) was used for incidence frequency data included in the "iNEXT()" function of the iNEXT package (Hsieh et al., 2016). Hill numbers present an exponent $q$ that determines their sensitivity to incidence frequency, where $q=0$ is equivalent to species richness, $q=1$ to diversity, and $q=2$ equitability (Hill , 1973; Chao et al., 2014).

\section{RESULTS}

76 pellets were collected, in which remains of fish, mollusks, and crustaceans were found (Figure 2). An average of $4.4 \pm 2.8$ fish per pellet was calculated (Figure 2). Sample coverage $\left(\hat{\mathrm{C}}_{\text {ind }}=0.94\right)$ points out that the results are representative of the diet of $N$. brasilianus for the period May-June 2017, with a confidence interval of 0.95. Thus, the probability of finding a new species if a new pellet were added to the sample is $0.06\left(1-\hat{\mathrm{C}}_{\text {ind }}\right)$ (Figure 3).

In the pellets, remains of undigested material from three groups were found: i) crustaceans, represented by an exoskeleton; ii) mollusks, represented by a bivalve valve, and iii) teleost fish, represented by spines, vertebrae, fins,

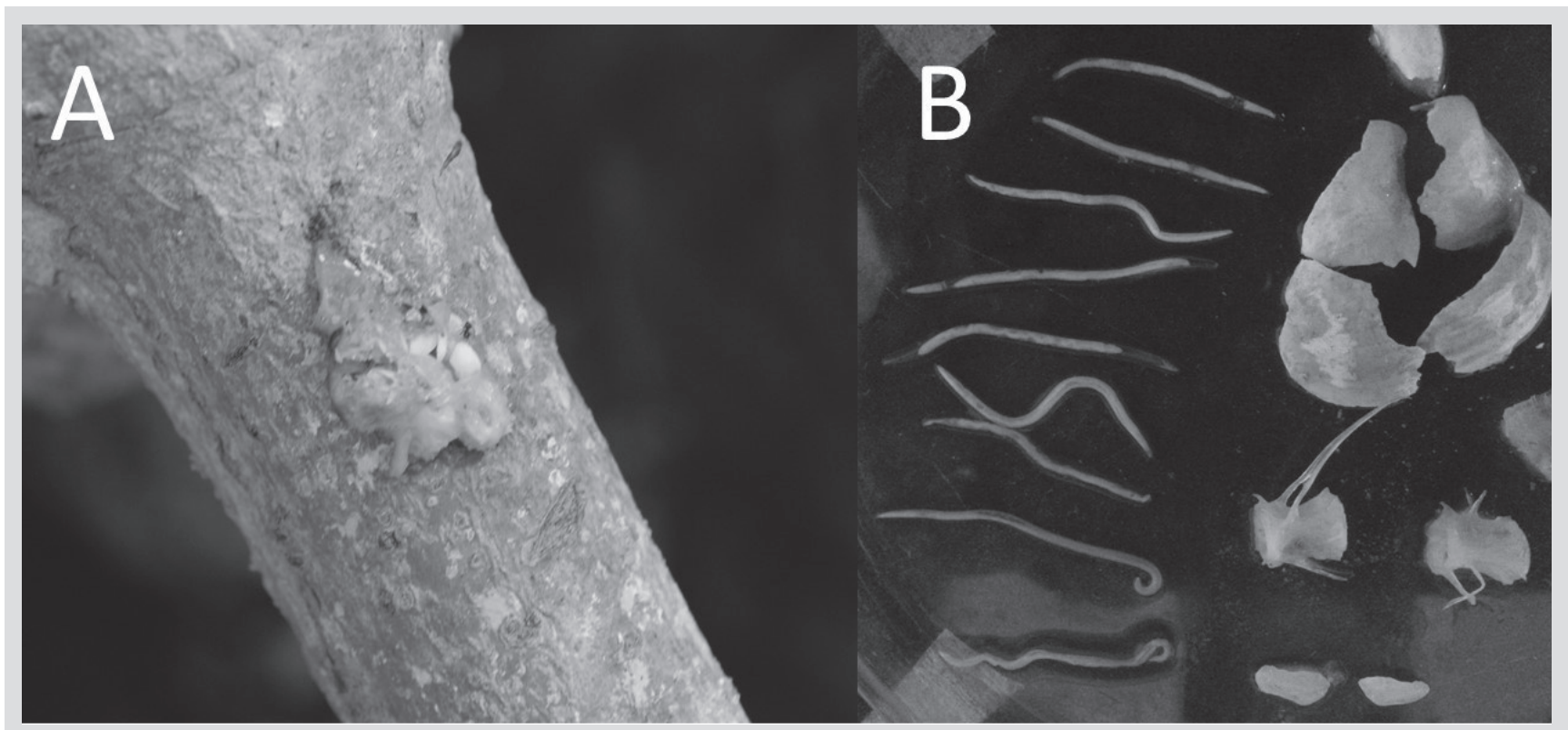

Figura 2. A) Egagrópilas de Nannopterum brasilianus sobre una raíz de Rhizophora mangle, L. B) Estructuras duras de las presas de $N$. brasilianus y parásitos que se observaron en una egagrópila procesada en laboratorio.
Figure 2. A) Nannopterum brasilianus pellets on a root of Rhizophora mangle, L. B) Hard structures of $N$. brasilianus prey and parasites that were observed in a laboratory-processed pellet. 


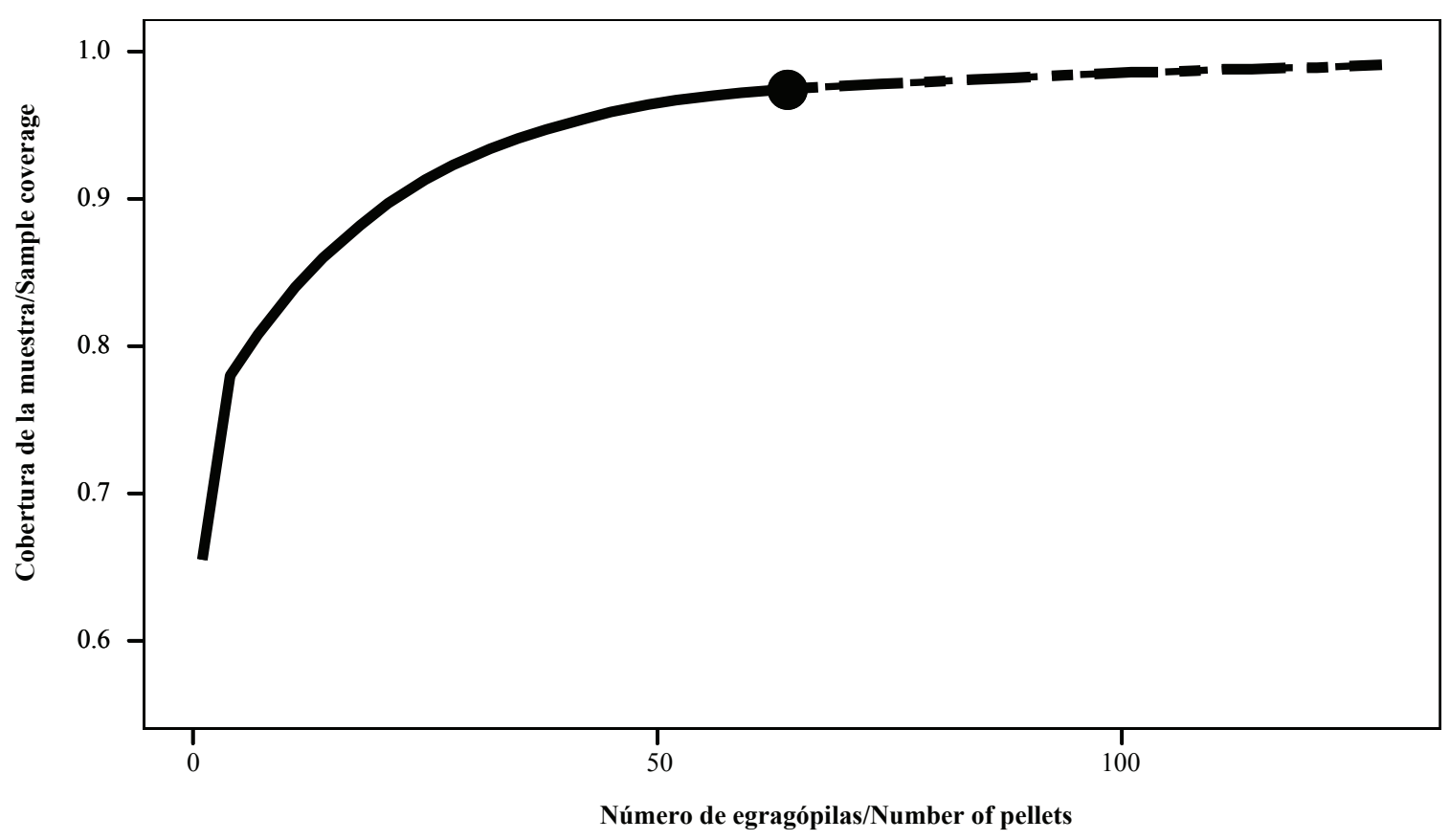

Figura 3. Curva de muestreo basada en la rarefacción (líneas continuas) y extrapolación (líneas punteadas) de la cobertura del muestreo de egagrópilas de Nannopterum brasilianus en la colonia de Punta Blanca, con intervalos de confianza del $95 \%$ (áreas sombreadas) recolectadas en mayo y junio de 2017.
Figure 3. Sampling curve based on the rarefaction (solid lines) and extrapolation (dotted lines) of the coverage of the pellet sampling of Nannopterum brasilianus in the Punta Blanca colony, with $95 \%$ confidence intervals (shaded areas) collected in May and June of 2017. por un exoesqueleto; ii) moluscos, representado por una valva de bivalvo, y iii) peces teleósteos, representados por espinas, vertebras, aletas, cráneos y otolitos. Del total de egagrópilas recolectadas, se encontraron otolitos en 64 $(84,2 \%)$ identificando ocho morfoespecies, cinco a nivel de especie, dos a nivel de género y una a nivel de familia (Figura 4).

En cuanto a la frecuencia de ocurrencia, la familia Ariidae presentó los valores más altos $(92,5 \% \mathrm{FO})$, seguido de Mugilidae (17,9\%FO). A nivel de especie, Cathorops mapale (Ariidae) se destacó por su presencia en gran parte de las egagrópilas $(92,1 \%$ FO) (Tabla 1). En cuanto al porcentaje en número, se observó un total de 275 individuos presa en las muestras, la mayoría pertenecientes a la familia Ariidae, seguido de lejos por Mugilidae y Engraulidae (93,7, 4,9 y $0,4 \% \mathrm{~N}$, respectivamente). La especie con mayor representatividad en número fue $C$. mapale $(89,5 \% \mathrm{~N})$, seguida de Mugil liza (Mugilidae) con un 2,2 \%N. La amplitud del nicho estimada para Nannopterum brasilianus mostró un comportamiento especialista $\left(B_{j}=0,02\right)$ mientras que la riqueza de especies en la dieta $(\mathrm{q}=0)$ fue de un número efectivo de 12 especies igualmente frecuentes, la diversidad trófica $(\mathrm{q}=1)$ fue 3,9 y la equitatividad $(\mathrm{q}=2)$ fue de 2,1 . skulls, and otoliths. Of the total of pellets collected, otoliths were found in $64(84.2 \%)$ of them, and in total, eight morpho-species were identified from the otoliths: five at the species level, two at the genus level, and one at the family level (Figure 4).

In the frequency of occurrence, the Ariidae family presented the highest values (92.5\%FO), followed by Mugilidae (17.9\%FO). At the species level, Cathorops mapale (Ariidae) stood out for its presence in a large part of pellets (92.1\%FO) (Table 1). Regarding the numerical frequency, a total of 275 prey individuals were observed in the samples. Most belonging to the Ariidae family, followed far behind by Mugilidae and Engraulidae (93.7, 4.9, and 0.4 $\% \mathrm{~N}$, respectively). The species with the highest numerical frequency was $C$. mapale $(89.5 \% \mathrm{~N})$, followed by Mugil liza (Mugilidae) with $2.2 \% \mathrm{~N}$. The niche width for Nannopterum brasilianus presented a specialist behaviour of 0.02 . While the richness of species in the diet $(q=0)$ was an effective number of 12 equally frequent species, trophic diversity $(q$ $=1)$ was 3.9 and fairness $(q=2)$ was 2.1 . 


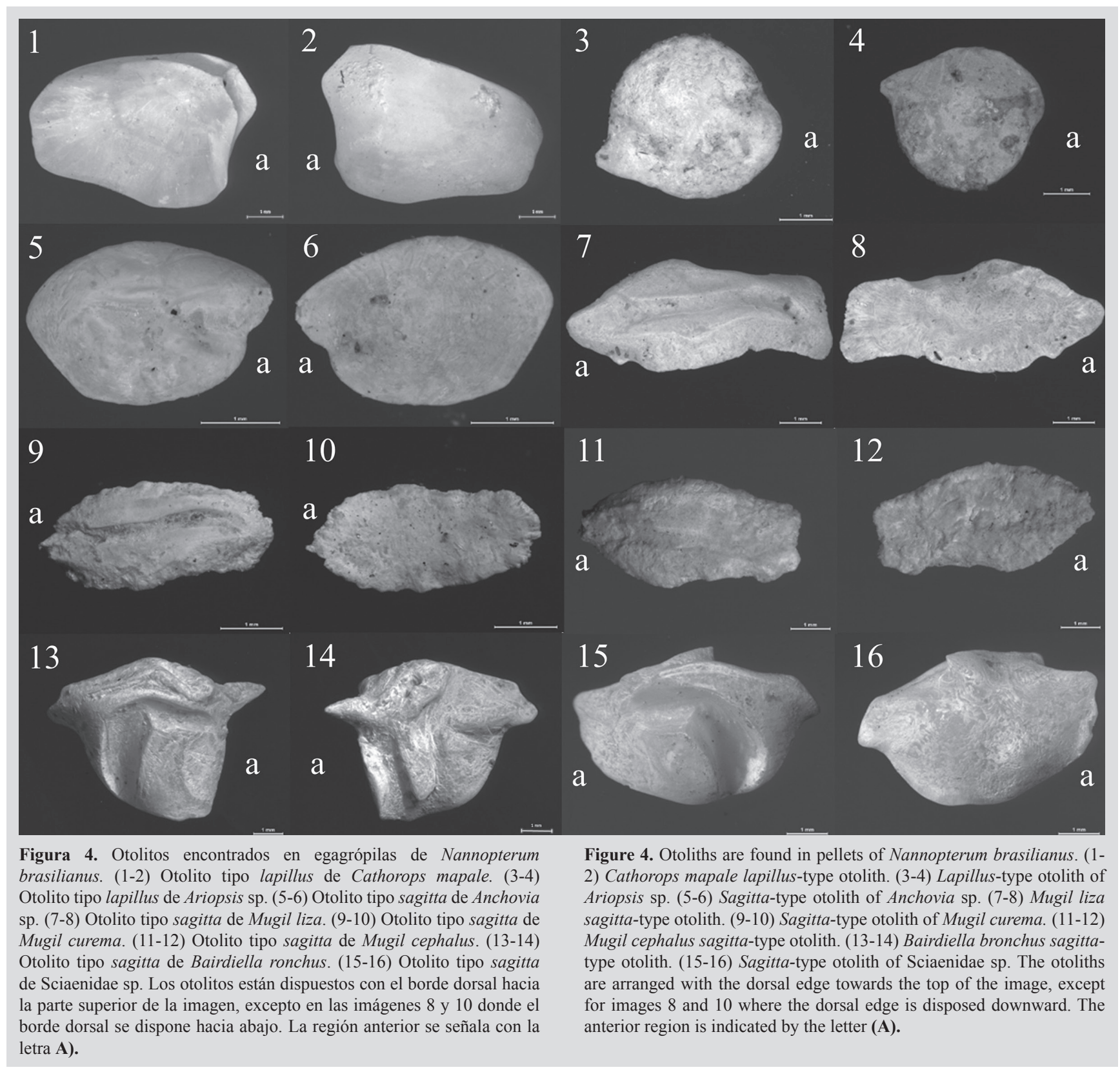

Tabla 1. Medidas relativas de cuantificación de presas de los ítems encontrados en las egagrópilas de Nannopterum brasilianus entre mayo y junio del 2017 en el CL-CGSM. \%FO: frecuencia de ocurrencia. \%N: porcentaje en número.

Table 1. Relative measures of prey quantification of the items found in Nannopterum brasilianus pellets between May and June 2017 in the CGSM LC. \%FO: Frequency of occurrence. \%N: Numerical frequency.

\begin{tabular}{|l|r|r|c|}
\hline \multicolumn{1}{|c|}{ Familia/Family } & Especie/Species & \%FO & \%N \\
\hline Ariidae & & 92.5 & 93.7 \\
& Cathorops mapale Betancur y Acero, 2005 & 92.1 & 89.5 \\
& Ariopsis sp. Peyer, 1928 & 6.3 & 1.9 \\
\hline
\end{tabular}




\begin{tabular}{|c|c|c|c|}
\hline Familia/Family & Especie/Species & $\%$ FO & $\% \mathbf{N}$ \\
\hline \multicolumn{2}{|l|}{ Mugilidae } & 17.9 & 4.8 \\
\hline & Mugil liza Valenciennes, 1836 & 9.5 & 2.2 \\
\hline & Mugil curema Valenciennes, 1836 & 4.8 & 1.1 \\
\hline & Mugil cephalus Linnaeus, 1758 & 4.8 & 1.5 \\
\hline \multirow[t]{3}{*}{ Sciaenidae } & & 4.5 & 1.1 \\
\hline & Bairdiella ronchus (Cuvier, 1830) & 3.2 & 0.7 \\
\hline & Sciaenidae sp. & 1.6 & 0.4 \\
\hline Engraulidae & Anchovia sp. Jordan \& Evermann, 1895 & 1.6 & 0.4 \\
\hline \multicolumn{2}{|c|}{ No identificados/Unidentified } & 10.9 & 2.5 \\
\hline
\end{tabular}

\section{DISCUSIÓN}

La completitud de los muestreos es un parámetro importante a la hora de realizar comparaciones entre diferentes estudios (Chao et al., 2014). Sin embargo, las investigaciones revisadas sobre la dieta de $N$. brasilianus en Latinoamérica no precisan esta información (Tabla 2). En este sentido, los resultados obtenidos en el presente estudio pueden servir de línea base para futuras investigaciones que deseen evaluar con mayor certeza diferencias espaciales y temporales en la ecología trófica de la especie, especialmente cuando se tienen periodos o coberturas espaciales limitadas como en este estudio.

La dieta de $N$. brasilianus estuvo representada por peces bentónicos y demersales mientras que los moluscos y crustáceos se consideraron como ingesta indirecta, conforme a lo registrado en otros estudios (Regidor y Terroba, 2001; Barquete et al., 2008; Muñoz et al., 2008; Petracci et al., 2009). La familia Ariidae estuvo representada por dos especies en la dieta del cormorán, que significaron casi su totalidad tanto en frecuencia de ocurrencia como en porcentaje en número. Esta familia de peces tiene hábitos de vida bentónicos, ideales para el tipo de captura por buceo, característico de los cormoranes (Mejía-Ladino et al., 2002; Barquete et al., 2008). Los resultados corroboran la importancia de esta familia de peces en la dieta del cormorán neotropical, registrada en otros países tropicales como Brasil y Venezuela (Tabla 2).

\section{DISCUSSION}

The completeness of the samplings is an important parameter when making comparisons between different studies (Chao et al., 2014). However, the researchers reviewed that the diet of $N$. brasilianus in Latin America does not require this information (Table 2). In this sense, the results obtained in the present study can serve as a baseline for future investigations that wish to evaluate spatial and temporal differences in the trophic ecology of the species with greater certainty, especially when you have limited periods or spatial coverage as in this study.

The diet of $N$. brasilianus was represented by benthic and demersal fish, while mollusks and crustaceans were considered as indirect ingestion, as reported in other studies (Regidor and Terroba, 2001; Barquete et al., 2008; Muñoz et al., 2008; Petracci et al., 2009). The Ariidae family was represented by two species in the cormorant diet, which represented almost all of them both in the frequency of occurrence and in numerical frequency. This family of fish has benthic life habits, ideal for the type of capture by diving, characteristic of cormorants (Mejía-Ladino et al., 2002; Barquete et al., 2008). The results corroborate the importance of this family of fish in the diet of the Neotropical cormorant, reported in other tropical countries such as Brazil and Venezuela (Table 2). 
Tabla 2. Familias de peces encontradas en la dieta del cormorán neotropical en otras regiones de Suramérica y en la Ciénaga Grande de Santa Marta (CGSM). \%N: frecuencia numérica. \%FO: frecuencia de ocurrencia.
Table 2. Fish families found in the diet of the Neotropical cormorant in other regions of South America and the Ciénaga Grande de Santa Marta (CGSM). \%N: numerical frequency. \%FO: frequency of occurrence.

\begin{tabular}{|c|c|c|c|c|c|c|c|c|c|c|}
\hline Fuente/Source & $\begin{array}{l}\text { Hennig } \\
\text { (1997) }\end{array}$ & $\begin{array}{l}\text { Gil de Weir } \\
\text { et al. (2011) }\end{array}$ & \multicolumn{2}{|c|}{ Barquete et al. (2008) } & $\begin{array}{c}\text { Muñoz } \\
\text { et al. (2008) }\end{array}$ & $\begin{array}{c}\text { Petracci } \\
\text { et al. (2009) }\end{array}$ & \multicolumn{2}{|c|}{ Alarcon et al. (2012) } & \multicolumn{2}{|c|}{$\begin{array}{l}\text { Este estudio/ } \\
\text { This study }\end{array}$} \\
\hline $\begin{array}{l}\text { Área de estudio/ } \\
\text { Study area }\end{array}$ & CGSM & $\begin{array}{c}\text { Ciénaga } \\
\text { los Olivos } \\
\text { (Venezuela) }\end{array}$ & \multicolumn{2}{|c|}{$\begin{array}{c}\text { Lago Dos Patos/ } \\
\text { Dos Patos Lake } \\
\text { (Brasil) }\end{array}$} & $\begin{array}{c}\text { Península } \\
\text { de Araya/ } \\
\text { Araya } \\
\text { Peninsula } \\
\text { (Venezuela) }\end{array}$ & $\begin{array}{c}\text { Bahía } \\
\text { Blanca/ } \\
\text { Blanca Bay } \\
\text { (Argentina) }\end{array}$ & \multicolumn{2}{|c|}{$\begin{array}{l}\text { Río Limay/ } \\
\text { Limay River } \\
\text { (Argentina) }\end{array}$} & & \\
\hline $\begin{array}{l}\text { Año de estudio/ } \\
\text { Year of study }\end{array}$ & 1996-1997 & 1998-1999 & \multicolumn{2}{|c|}{ 2001-2002 } & $2003-2004$ & $2003-2006$ & \multicolumn{2}{|c|}{2008} & \multicolumn{2}{|c|}{2017} \\
\hline Muestras/Samples & $\begin{array}{l}\text { Estómago y } \\
\text { vomitados/ } \\
\text { Stomach and } \\
\text { vomiting }\end{array}$ & $\begin{array}{c}\text { Estómagos y } \\
\text { egagrópilas/ } \\
\text { Stomachs } \\
\text { and pellets }\end{array}$ & \multicolumn{2}{|c|}{$\begin{array}{l}\text { Egagrópilas/ } \\
\text { Pellets }\end{array}$} & $\begin{array}{l}\text { Estómagos/ } \\
\text { Stomaches }\end{array}$ & $\begin{array}{l}\text { Egagrópilas/ } \\
\text { Pellets }\end{array}$ & \multicolumn{2}{|c|}{$\begin{array}{l}\text { Egagrópilas/ } \\
\text { Pellets }\end{array}$} & \multicolumn{2}{|c|}{$\begin{array}{l}\text { Egagrópilas/ } \\
\text { Pellets }\end{array}$} \\
\hline $\mathrm{n}$ & 13 y 53 & 73 y 40 & \multicolumn{2}{|c|}{289} & 34 & 200 & \multicolumn{2}{|c|}{106} & \multicolumn{2}{|c|}{76} \\
\hline $\begin{array}{l}\text { Cobertura } \\
\text { de la muestra/ } \\
\text { Sample coverage }\end{array}$ & --- & --- & \multicolumn{2}{|c|}{---} & --- & --- & \multicolumn{2}{|c|}{--- } & \multicolumn{2}{|c|}{$94 \%$} \\
\hline Índice/Index & $\% \mathrm{~N}$ & $\% \mathrm{~N}$ & $\% \mathrm{FO}$ & $\% \mathrm{~N}$ & $\% \mathrm{~N}$ & $\% \mathrm{FO}$ & $\% \mathrm{FO}$ & $\% \mathrm{~N}$ & $\% \mathrm{FO}$ & $\% \mathrm{~N}$ \\
\hline Ariidae & 23.4 & 41.0 & 43.6 & 10.3 & 45.0 & - & - & - & 92.5 & 93.7 \\
\hline Mugilidae & 1.1 & $<2.0$ & 20.0 & 2.8 & ¿? & - & - & - & 17.9 & 4.8 \\
\hline Sciaenidae & - & 4.0 & 73.7 & 43.3 & - & 13.0 & - & - & 4.5 & 1.1 \\
\hline Engraulidae & 67.1 & 32.0 & 18.3 & 27.4 & 7.5 & - & - & - & 1.6 & 0.4 \\
\hline Gerreidae & 6.1 & 11.0 & - & - & - & - & - & - & - & - \\
\hline Atherinopsidae & - & - & 1.0 & 0.1 & - & 9.0 & 1.1 & 0.2 & - & - \\
\hline Dactylopteridae & - & - & - & - & 10.0 & - & - & - & - & - \\
\hline Batrachoididae & - & - & - & - & 27.0 & 90.0 & - & - & - & - \\
\hline Salmonidae & - & - & - & - & - & - & 98.9 & 60.3 & & \\
\hline Galaxidae & - & - & - & - & - & - & 9.6 & 3.6 & - & - \\
\hline Percichthyidae & - & - & - & - & - & 0.5 & 6.4 & 1.1 & - & - \\
\hline $\begin{array}{l}\text { Invertebrados/ } \\
\text { Invertebrates }\end{array}$ & - & - & 5.8 & 0.3 & - & 15.0 & 55.3 & 20.1 & - & - \\
\hline Otros/Others & 2.3 & 13.5 & - & 15.2 & - & - & 50.0 & 14.7 & - & - \\
\hline
\end{tabular}

El registro relativamente alto de C. mapale en la dieta del cormorán neotropical durante este estudio coincidió con los altos desembarcos pesqueros registrados para $C$. mapale en el CL CGSM durante el mes de mayo de 2017, cuando fue la segunda especie más capturada con un total de 330,5 toneladas (Invemar, 2020). Por su lado, Hening (1997) registró que la dieta de $N$. brasilianus durante la reproducción en agosto del 1996 estuvo dominada en un $92,99 \%$ por individuos pertenecientes a la subfamilia
The relatively high record of $C$. mapale in the diet of the Neotropical cormorant during this study coincided with the high fishing landings recorded for C. mapale in the CGSM LC during May 2017, when it was the second most captured species with a total of 330.5 tons (Invemar, 2020). On the other hand, Hening (1997) reported that the diet of $N$. brasilianus during the reproduction of the cormorant, in August 1996, was dominated by $92.99 \%$ by individuals belonging to the subfamily Engraulidae 
Engraulidae (Anchovia clupeoides y Cetengraulis edentulus). Sin embargo, estas especies representaron menos del $1 \%$ de las capturas registradas en el CL CGSM en ese mismo año. No obstante, Manjarrés et al. (2007) registraron que $C$. edentulus fue la especie más importante en los desembarcos pesqueros provenientes del área marina adyacente al CL CGSM, entre 1994 y 1998, siendo especialmente abundante en 1996 cuando se estimaron capturas de aproximadamente 484 toneladas. Esto indica que los individuos de $N$. brasilianus pertenecientes a la colonia ubicada al nororiente del SFF CGSM pueden alimentarse en el mar Caribe, en busca de individuos que tengan los tamaños adecuados para ser consumidos.

Es importante mencionar que el presente estudio, aunque complementario, no es comparable con el de Hennig (1997). Esto se debe principalmente a que ese autor analizó estómagos y vomitados durante condiciones climáticas influenciadas por una fase cálida del evento El Niño Oscilación Sur (ENOS), mientras que en el presente estudio se analizaron egagrópilas durante una fase neutral del ENOS (NOAA, 2020). En efecto, para el CL CGSM se ha registrado que el ENOS incide en la abundancia de las especies de peces e invertebrados capturadas por la flota pesquera artesanal (Invemar, 2019).

La importancia numérica de la familia Mugilidae en la dieta de $N$. brasilianus fue más significativa que en otros estudios; sin embargo, en términos de ocurrencia fue similar a Barquete et al. (2008) (Tabla 2). Esto corrobora la importancia de los mugilidos en la dieta de la familia Phalacrocoracidae, donde son presas recurrentes (Jahncke $y$ Goya, 1997; Olmos et al., 2000). Cabe mencionar que Hennig (1997) identificó en la dieta del cormorán sólo una especie de esta familia (M. incilis), mientras que en el presente estudio se lograron identificar tres especies (M. liza, M. curema, y M. cephalus), cuyas dietas están dominadas por la producción primaria del complejo lagunar (detritos, diatomeas y sedimentos inorgánicos), por lo que desempeñan un rol importante en la transferencia de energía del sistema estuarino hacia los cormoranes (Jacot, 1920; Osorio, 1988).

Los peces de la familia Sciaenidae tuvieron una contribución menor en la dieta de $N$. brasilianus, indicando un consumo esporádico, similar a otros estudios (Hennig, 1997; Olmos et al. 2000; Gil de Weir et al. 2011). Por el contrario, Barquete et al. (2008) encontraron que la familia Sciaenidae hizo la mayor contribución en número y ocurrencia, lo cual coincidió con la alta abundancia de Micropogonia furnieri (Desmarest, 1823) en aguas profundas y sitios con mayor
(Anchovia clupeoides and Cetengraulis edentulus). However, these species represented less than $1 \%$ of the catches recorded in the CGSM LC during that year. However, Manjarrés et al. (2007) reported that C. edentulus was the most important species in the fishing landings from the marine area adjacent to the CGSM LC, between 1994 and 1998, being especially abundant in 1996 when catches of approximately 484 tons were estimated. This indicates that the individuals of $N$. brasilianus belonging to the colony located to the northeast of the CGSM FFS can feed in the Caribbean Sea, in search of individuals that have the adequate sizes to be consumed.

It is important to mention that the present study, although it is complementary, is not comparable with that of Hennig (1997). This is mainly because this author analyzed stomachs and vomits during climatic conditions influenced by a warm phase of the El Niño Southern Oscillation (ENSO) event, while in the present study pellets were analyzed during a neutral phase of ENSO (NOAA, 2020). Indeed, for the CL CGSM it has been reported that ENSO affects the abundance of fish and invertebrate species caught by the artisanal fishing fleet (Invemar, 2019).

The numerical frequency of the Mugilidae family in the $N$. brasilianus diet was more significant than in other studies; however, in terms of occurrence it was similar to Barquete et al. (2008) (Table 2). This corroborates the importance of Mugilidae in the diet of Phalacrocoracidae, where they are recurrent prey (Jahncke and Goya, 1997; Olmos et al., 2000). It is worth mentioning that Hennig (1997) identified only one species of this family ( $M$. incilis) in the cormorant diet, while in the present study three species were identified (M. liza, M. curema, and $M$. cephalus), whose diets are based on the primary production of the lagurnar complex (debris, diatoms, and inorganic sediments), for which they play an important role in the transfer of energy from the estuarine system to cormorants (Jacot, 1920; Osorio, 1988).

The fish of the Sciaenidae family had a minor contribution to the $N$. brasilianus diet, indicating sporadic consumption, similar to other studies (Hennig, 1997; Olmos et al., 2000; Gil de Weir et al., 2011). On the contrary, Barquete et al. (2008) found that the Sciaenidae family made the highest contribution in numerical frequency and occurrence, which coincided with the high abundance of Micropogonia furnieri (Desmarest, 1823) in deep waters and sites with greater marine influence (Marín 
influencia marina (Marín et al., 2013). Esto se explica porque la importancia de esta familia en la dieta del cormorán es mayor en poblaciones que habitan en ecosistemas marinos (Petracci et al., 2009).

La familia Engraulidae tuvo poca ocurrencia e importancia numérica en la dieta, en contraste con estudios previos que registran una contribución mayor de esta familia en la dieta de $N$. brasilianus (Tabla 2). La disminución en la población de Cetengraulis edentulus (Cuvier, 1829), inferida por la tendencia decreciente de sus desembarcos y la captura de juveniles, llevaron a que fuese categorizada como casi amenazada en la región (Duarte et al., 2017), lo cual plantea una reducción en su oferta como alimento para el cormorán. Respecto a Anchovia clupeoides (Swainson, 1839), Hennig (1997) registra una talla media de consumo de $14 \mathrm{~cm}$ (entre $10-20 \mathrm{~cm}$ ), y la talla media de captura por pescadores se ha reducido de $19 \mathrm{~cm}$ (longitud total en 1999) a $12 \mathrm{~cm}$ (longitud total en mayo y junio de 2017) (Invemar, 2020). Esto sugiere que la explotación pesquera de $A$. clupeoides podría haber afectado la disponibilidad de las presas con tallas apetecibles para $N$. brasilianus.

Con base en estudios de ecología trófica, se ha considerado que $N$. brasilianus es una especie generalista $\mathrm{u}$ oportunista que selecciona sus presas en función de la disponibilidad y la cual aprovecha los recursos más abundantes y fáciles de capturar (Conde-Tinco y Iannacone, 2013; Ovegård, 2017). La amplitud de nicho observada en el presente estudio sugiere un hábito especialista, lo cual se corrobora con los valores de diversidad y equitatividad trófica. Sin embargo, al considerar la riqueza de especies en la dieta y en conformidad a lo registrado por Hennig (1997), podría ser un caso de "especialización temporal" como el descrito por Barquete et al. (2008) para el cormorán neotropical en el lago Dos Patos al sur de Brasil y moldeado por la teoría de forrajeo optimo (Valdovinos et al., 2010). Para especies de cormoránes, se conoce que la puesta y la eclosión de los huevos son asíncronas y están probablemente relacionadas con la oferta de alimentos más disponibles y parecen permitir una respuesta rápida a las condiciones ambientales (Siegel-Causey, 1997). Este caso de la relación entre el éxito reproductivo y la oferta alimentaria se ha observado en otras aves piscívoras, como el caso de los pelícanos y su éxito reproductivo debido a los eventos de surgencia de aguas frías temporales que concentran agregaciones de peces presa en meses de manera predecible (Pelecanus occidentalis en México: Hernández-Vázquez et al., 2011; en Panamá: Martínez, 1983; en Gorgona: Falk-Fernández, 1993). et al., 2013). This is explained because the importance of this family in the cormorant diet is greater in populations that inhabit marine ecosystems (Petracci et al., 2009).

The family Engraulidae had little occurrence and numerical frequency in the diet, in contrast to previous studies that record a greater contribution of this family in the diet of $N$. brasilianus (Table 2). The decrease in the Cetengraulis edentulus population (Cuvier, 1829), inferred by the decreasing trend of its landings and the capture of juveniles led to it being categorized as near threatened in the region (Duarte et al., 2017), which poses a reduction in its supply as food for the cormorant. Regarding Anchovia clupeoides (Swainson, 1839), Hennig (1997) reports an average consumption length of $14 \mathrm{~cm}$ (between 10$20 \mathrm{~cm}$ ), and the average size of catch by fishermen has been decreasing from $19 \mathrm{~cm}$ (total length in 1999) to 12 cm (total length in May and June 2017) (Invemar, 2020). This suggests that the fishing exploitation of $A$. clupeoides could have affected the availability of prey with palatable sizes for consumption by $N$. brasilianus.

Based on trophic ecology studies, N. brasilianus has been considered to be a generalist or opportunistic species, which selects its prey based on availability and which takes advantage of the most abundant and easyto-capture resources (Conde-Tinco and Iannacone, 2013; Ovegård, 2017). The niche width observed in the present study suggests a specialist habit, which is corroborated by the values of trophic diversity and equitability. However, when considering the richness of species in the diet and in accordance with that reported by Hennig (1997), it could be a case of "temporal specialization" as described by Barquete et al. (2008) for the Neotropical cormorant in Dos Patos Lake in southern Brazil and modeled by the optimal foraging theory (Valdovinos et al., 2010). For cormorant species, egg-laying and hatching are known to be asynchronous, and are probably related to the supply of more available food and seem to allow a rapid response to environmental conditions (Siegel-Causey, 1997). This case of the relationship between reproductive success and food supply has been observed in other piscivorous birds, such as the case of pelicans and their reproductive success due to the upwelling events of temporary cold waters that concentrate aggregations of prey fish in months of predictably (Pelecanus occidentalis in Mexico: Hernández-Vázquez et al., 2011; in Panama: Martínez, 1983; in Gorgona: Falk-Fernández, 1993). 


\section{CONCLUSIONES}

Nannopterum brasilianus presentó un hábito alimentario especializado durante su anidación del año 2017, pero los valores de riqueza en la dieta y los antecedentes sugieren que es un ave generalista y lo observado corresponde a una respuesta adaptativa moldeada por la disponibilidad de presas. Sin embargo, se requieren estudios más amplios en tiempo y espacio para corroborar lo planteado.

El uso de egagrópilas en el estudio de la dieta del cormorán es un método informativo, poco invasivo y no letal, pero presenta desafíos para su implementación optima en el CL CGSM, como es la ausencia de registros de otolitos de las presas potenciales presentes en el ecosistema, así como análisis de correlación entre el tamaño de los otolitos y las tallas de los peces. Debido a que no se cuentan con dichos insumos, no se pudieron identificar todos los componentes de la riqueza de presas, ni calcular las tallas de las presas consumidas.

\section{AGRADECIMIENTOS}

Los autores agradecen al SFF CGSM y a la Dirección Territorial Caribe de Parques Nacionales Naturales de Colombia (DTCA) por el apoyo técnico, logístico y administrativo ofrecido durante el transcurso de la investigación. También agradecen al grupo de investigación Evaluación y Ecología Pesquera de la Universidad del Magdalena (GIEEP) por facilitar sus laboratorios y equipos para el procesamiento de las muestras y a la Asociación para el Estudio y la Conservación de las Aves Playeras de Colombia (Calidris) por sus aportes durante la fase inicial de la investigación.

\section{CONCLUSIONS}

Nannopterum brasilianus presented a specialized feeding habit during its nesting in 2017, but the richness values in the diet and the antecedents suggest that it is a generalist bird and the observed corresponds to an adaptive response modeled because of the availability of dams. However, larger studies are warranted in time and space to corroborate what has been raised.

The use of pellets in the study of the cormorant diet is an informative, minimally invasive, and non-lethal method, but it presents challenges for its optimal implementation in the CGSM LC, such as the absence of otolith records of the potential prey present in the ecosystem, as well as correlation analysis between the size of the otoliths and the sizes of the fish. Since these inputs are not available, it was not possible to identify all the components of the richness of prey, nor to calculate the sizes of the prey consumed.

\section{ACKNOWLEDGEMENTS}

The authors thank the CGSMFFS and the Caribbean Territorial Directorate of Natural National Parks of Colombia (DTCA) for the technical, logistical, and administrative support offered during the investigation. They also thank the Evaluation and Fisheries Ecology Research Group of the University of Magdalena (GIEEP) for providing their laboratories and equipment for processing the samples and the Asociación para el Estudio y la Conservación de las Aves Playeras de Colombia (Calidris) for their contributions during the initial phase of the investigation.

\section{BIBLIOGRAFÍA/LITERATURE CITED}

Abilhoa, V. y M.F.M. Correa. 1992. Catálogo de otólitos de Carangidae (Osteichthyes-Perciformes) do litoral do Estado do Paraná, Brasil. Nerítica, 7(1-2):119131.

Andrade-Amaya, C.A. 2000. The circulation and variability of the Colombian Basin in the Caribbean Sea. Tesis Ph. D., Univ. Wales. 223p.

Assis, C.A. 2003. The Lagenar otoliths of teleosts: their morphology and its application in species identification, phylogeny and systematics. J. Fish Biol., 62(6): $1268-1295$

Assis, C.A. 2005. The utricular otoliths, lapilli, of teleosts: their morphology and relevance for species identification and systematics studies. Sci. Mar., 69(2): 259-273.

Barquete, V., L. Bugoni y C.M. Vooren. 2008. Diet of Neotropic cormorant (Phalacrocorax brasilianus) in an estuarine environment. Mar. Biol., 153(3): 431-443.

BirdLife International. 2018. Important bird areas factsheet: Ciénaga Grande, isla de Salamanca and Sabana Grande Ramsar Biosphere Reserve. http://www. birdlife.org. 17/07/2020. 
Blanco, J.A., E.A. Viloria, and J.C. Narváez. 2006. ENSO and salinity changes in the Ciénaga Grande de Santa Marta coastal lagoon system, Colombian Caribbean. Estuar. Coast Shelf Sci., 66(1-2): 157-167.

Bó, M., A. Baladrón y L. Biondi. 2007. Ecología trófica de falconiformes y strigiformes: tiempo de síntesis. Hornero, 22(2): 97-115.

Botero, L. y H. Salzwedel. 1999. Rehabilitation of the Ciénaga Grande de Santa Marta, a mangrove-estuarine system in the Caribbean coast of Colombia. Ocean Coast Manage., 42(2-4): 243-56.

Chao, A., N.J. Gotelli, T.C. Hsieh, E.L. Sander, K.H. Ma, R.K. Colwell, and A.M. Ellison. 2014. Rarefaction and extrapolation with Hill numbers: a framework for sampling and estimation in species diversity studies. Ecol. Monogr., 84(1): 45-67.

Conde-Tinco, M.A. y J. Iannacone. 2013. Bioecología de Phalacrocorax brasilianus (Gmelin, 1789) (Pelecaniformes: Phalacrocoracidae) en Sudamérica. Biologist, 11(1): 151-166.

Dias, E., P. Morais, M. Leopold, J. Campos, and C. Antune. 2012. Natural born indicators: Great cormorant Phalacrocorax carbo (Aves: Phalacrocoracidae) as monitors of river discharge influence on estuarine ichthyofauna. J Sea Res, 73: 101-108.

Duarte, L.O., L. Manjarrés y J. Leal. 2017. Cetengraulis edentulus (Cuvier, 1829). En: Chasqui L., A. Polanco, A. Acero P., P. Mejía-Falla, A. Navia, L.A. Zapata, J.P. Caldas (Eds.). Libro rojo de los peces marinos de Colombia. Ser. Publ. Gener. Invemar, (93). Santa Marta. 552 p.

Espino-Barr, E., M. Gallardo-Cabello, E.G. Cabral-Solís, M. Puente-Gómez y A. García-Boa. 2013. Otoliths analysis of Mugil curema (Pisces: Mugilidae) in Cuyutlan lagoon, Mexico. Av Investig. Agropecu., 17(1): 35-64.

Falk-Fernández, P. 1993. Variación poblacional y aspectos del ciclo reproductivo del pelícano (Pelecanus occidentalis murphy) en el Parque Nacional Natural Gorgona. Tesis Biol., Univ. Valle. 71 p.

García, C.B., L.O. Duarte y G. Ramírez. 2013. Fisiografía y oceanografía del golfo de Salamanca (mar Caribe, Colombia). 111-140. En: Melgarejo L.M. y C.B. García-Ramírez (Eds.). Investigación en ciencias del mar: aportes de la Universidad Nacional de Colombia. Universidad Nacional de Colombia, Bogotá $200 \mathrm{p}$.

Gil de Weir, K., E. Weir, C.L. Casler y S. Aniyar. 2011. Ecological functions and economic value of the Neotropic cormorant (Phalacrocorax brasilianus) in Los Olivitos estuary, Venezuela. Environ. Dev. Econ., 16(5): 553-572.

Hennig, V. 1997. Investigaciones sobre la biología del cormorán o pato cuervo (Phalacrocorax brasilianus) en la Ciénaga Grande de Santa Marta, Colombia. Deutsche Gesellschaft für Technische Zusammenarbeit (GTZ), Alemania. $41 \mathrm{p}$.

Hernández-García, R., J.A. Martínez-Pérez, T.A. Bautista-López y J.M. Reséndiz-Rodríguez. 2004. Descripción morfológica de los otolitos de las familias Engraulidae, Haemulidae y Achiridae del sistema estuarino de Tecolutla, Veracruz. Rev. Zool., 15: 7-13.

Hernández-Vázquez, S., E. Iñigo-Elías, J.Á. Hinojosa Larios, B. Durand Martínez, J.A. Rojo-Vázquez y C. Valadez-González. 2011. Abundancia y reproducción del pelícano pardo (Pelecanus occidentalis) en dos pequeñas bahías del Pacífico central, México. Acta Zool. Mex., 27(2): 257-271.

Hill, M.O. 1973. Diversity and evenness: a unifying notation and its consequences. Ecology, 54(2): 427-432.

Hsieh, T.C., K.H. Ma., and A. Chao. 2016. iNEXT: An R package for rarefaction and extrapolation of species diversity (Hill numbers). Methods Ecol. Evol., 7(12): 1451-1456.

Hureau, J.C. 1970. Biologie comparée de quelques poissons antarctiques (Nototheniidae). Expéditions Polaires Françaises, París. 244 p.

Hyslop, E.J. 1980. Stomach contents analysis- a review of methods and their application. J. Fish Biol., 17: 411-429.

Invemar. 2019. Monitoreo de las condiciones ambientales y los cambios estructurales y funcionales de las comunidades vegetales y de los recursos pesqueros durante la rehabilitación de la Ciénaga Grande de Santa Marta. Informe Técnico Final 2018, Invemar, Santa Marta. 214 p.

Invemar. 2020. Sistema de información pesquera de Invemar-SIPEIN [base de datos]. http://sipein.invemar.org.co/informes/cpue/externos/. 18/06/2020.

Jacot, A.P. 1920. Age, growth and scale characters of the mullet Mugil cephalus and M. curema. Trans. Amer. Micr. Soc., 39(3): 199-229.

Jahncke, J. y E. Goya. 1997. Variación latitudinal y estacional en la dieta del guanay (Leucocarbo bougainvilli) y el piquero peruano (Sula variegata) en la costa peruana. Bol. Inst. Mar Perú, 16(1): 22-41.

Jost, L. 2006. Entropy and diversity. Oikos, 113(2): 363-375.

Lombarte, A., O. Chic, V. Parisi-Baradad, R. Olivella, J. Piera y E. García-Ladona. 2006. A web-based environment for shape analysis of fish otoliths. The AFORO database. Sci. Mar., 70(1): 147-152.

López-Calleja, V. 1995. Dieta de Zonotrichia capensis (Emberizidae) y Diuca diuca (Fringillidae): efecto de la variación estacional de los recursos tróficos y la riqueza de aves granívoras en Chile central. Rev. Chil. Hist. Nat., 68: 321-331.

Lorenz, J.J. y J.E. Serafy. 2006. Subtropical wetland fish assemblages and changing salinity regimes: implications for everglades restoration. Hydrobiología, 569: $401-422$ 
Manjarrés, L., S. Sánchez, C.A. López-Anaya, A. Suárez, L. Martínez, Castro, A. y L. Pacheco. 2007. Captura y esfuerzo de las pesquerías de pequeña escala en las áreas protegidas. En: Manjarrés, L. (Ed). Caracterización participativa de las pesquerías de pequeña escala de las áreas protegidas de la Territorial Caribe. Informe técnico final, Univ. Magdalena, Santa Marta. 86 pp.

Martínez, J.A., M.M.C. Arteaga, J.L.T. Musi y A.A.M. Aranda. 2007. Utilización de otolitos como herramienta en la determinación de especies. Rev. Zool., 181318.

Martínez, M.L. 1983. Biología reproductiva de Pelecanus occidentalis en relación con el afloramiento de la bahía de Panamá. Tesis Ph.D., Univ. Valle, Cali.

Muñoz, J., G. Marín, J. Andrade y R. Alzola. 2008. Notas sobre la dieta de la cotúa olivácea (Phalacrocorax olivaceus) en una laguna marino-costera de la península de Araya, Venezuela. Saber, 20(2): 253-258.

NOAA. 2020. Multivariate ENSO Index Version 2 (MEI.v2). https://psl.noaa.gov/enso/mei/. 2/10/2020.

Olmos, V., J. Aragoneses, J. L. Echevarrias y R. Oltra. 2000. Composición de la dieta e impacto del cormorán grande (Phalacrocorax carbo sinensis) de Santa Pola, Alicante, este de España. Ardeola, 47(2): 227-236.

Orta, J. 1992. Family Phalacrocoracidae (cormorants). 326-353. En: del Hoyo, J., A. Elliott y J. Sargatal (Eds.). Handbook of the birds of the world. Lynx Edicions, Barcelona.

Osorio, D. 1988. Ecología trófica de Mugil curema, M. incilis y M. liza (Pices: Mugilidae) en la Ciénaga Grande de Santa Marta, Caribe colombiano I. Análisis cualitativo y comparativo. An. Inst. Inv. Mar., 18: 113-126.

Ovegård, M. 2017. The interactions between cormorants and wild fish populations analytical methods and applications. Tesis Aquatic Resources. Univ. Agric. Sci., Lysekil. 55 p.

Petracci, P., J. Cereghetti, J. Martín y S. Obed. 2009. Dieta del biguá (Phalacrocorax olivaceus) durante la primavera en el estuario de bahía Blanca, Buenos Aires, Argentina. Hornero, 24(2): 73-78.

R Studio Team. 2020. R Studio: Integrated development environment for R. R Studio, Boston. http://www.rstudio.com/

Ramsar. 2017. Misión Ramsar de asesoramiento n. ${ }^{\circ}$ 82: Sitio Ramsar Sistema Delta Estuarino del río Magdalena Ciénaga Grande de Santa Marta. Informe. Convención Ramsar. 61 p.

Regidor, H. y A. Terroba. 2001. Hábitos alimentarios del biguá Phalacrocorax brasilianus (Gmelin 1789) (Aves, Phalacrocoracidae) en el noroeste de Argentina. Bol. Soc. Biol. Concepción, (72): 121-123.

Román-Palacios, C. y C. Román-Valencia. 2015. Hábitos tróficos de dos especies sintópicas de carácidos en una quebrada de alta montaña en los Andes colombianos. Rev Mex Biodivers, 86: 782-788

Rossi-Wongtschowski, C.L.D.B., A. Chalom, C.C. Siliprandi, M.R. Brenha-Nunes, V.R.M. Conversani, C. Santificetur y M.B. Giaretta. 2016. COSS-Brasil: Coleção de otólitos de peixes marinhos da região sudeste-sul do Brasil. Instituto Oceanográfico Universidade de São Paulo, São Paulo. www.usp.br/ cossbrasil

Ruiz-Guerra, C., D. Eusse, R. Johnston-González, L. Castillo, C. Angulo y A. González. 2012. Distribución de aves acuáticas de la ecorregión Ciénaga Grande de Santa Marta, costa Caribe colombiana. Calidris, Cali. 23 p.

Ruiz-Guerra, C., R. Johnston-González, L.F. Castillo-Cortés, Y. Cifuentes-Sarmiento, D. Eusse y F.A. Estela. 2008. Atlas de aves playeras y otras aves acuáticas en la Costa Caribe Colombiana. Calidris, Cali. 72 p.

Sánchez-Ramírez, C. y M. Rueda. 1999. Variación de la diversidad y abundancia de especies ícticas dominantes en el delta del río Magdalena, Colombia. Rev. Biol. Trop., 47(4): 1067-1079.

Siegel-Causey, D. 1997. The problems of being successful: managing interactions between humans and double-crested cormorants. Symposium on DoubleCrested Cormorants: Population Status and Management Issues in the Midwest: 5-14.

Valdovinos, F., P. Urbani y R. Ramos-Jiliberto. 2010. Análisis de las consecuencias del comportamiento adaptativo individual sobre la estabilidad poblacional: el caso del forrajeo óptimo. Rev. Chil. Hist. Nat., 83: 207-218.

Vilardy, S.P., J.A. González, B. Martín-López, E. Oteros-Rozas y C. Montes. 2012. Los servicios de los ecosistemas de la reserva de biosfera Ciénaga Grande de Santa Marta. Revibec, 19: 66-83.

Volpedo, A.V y D.D. Echeverría. 2000. Catálogo y claves de otolitos para la identificación de peces del mar argentino, vol. 1. Dunken, Buenos Aires. 69 p.

Zijlstra, M. and M.R. Van-Eerden. 1995. Pellet production and the use of otoliths in determining the diet of Cormorants Phalacrocorax carbo sinensis: trials with captive birds. Ardea, 83: 123-131. 